\title{
Forensic Accounting and Fraud Reduction Strategies in Developing Economy
}

\author{
${ }^{1}$ Adesola Adebayo AKANDE (Ph. D), Johnson Kolawole OLOWOOKERE ${ }^{2}$ \\ ${ }^{I}$ Department of Accounting and Finance, Faculty of Humanities, Social and Management Sciences, Elizade \\ University, Ilara-Mkin. Ondo state. Nigeria. \\ ${ }^{2}$ Accounting Department, Faculty of Management Sciences, Osun State University, Nigeria.
}

\begin{abstract}
This paper examined forensic accounting capability and useful strategies to minimize the effects of financial crimes and other related frauds in Nigeria economy. Various points at which preventive controls can be established were identified.Data were collected from two hundred and fifty five (255) respondents in the south-west geo-political zone of Nigeria and response on capability and suitability of using forensic accounting principles and measures to prevent undue practice that often arises via financial crimes in the economy were analyzed with Analysis of Variance Method. The results showed that the estimated Z-statistic was 115.3736.The critical table value of the Z-statistic at 5\% level of significance (95\% confidence level) was obtained as 1.645. Since the estimated test statistic (Z-statistic) value exceeds the critical table value at 95\% confidence level, the null hypothesis is rejected in favour of the alternative hypothesis. Thus, the study concludes that forensic Accounting principles is capable of eliminating all types of financial frauds in any economy. It was also empirically found that forensic accounting can be used to locate diverted funds or assets, identify misappropriated assets and identified reversible insider transactions, thus, forensic accounting is useful as effective fraud detection tool, detects suspicious fraudulent transactions and covers risk assessment processes. Based on the above the study recommends the adoption of forensic accounting principles, effective appropriation of financial resources and external auditors employment..
\end{abstract}

Key words: Forensic, Larceny, Legislation, Frauds, Crime Spy-software, Strategies

\section{Introduction}

Generally, forensic Accounting can be described as the process of gathering relevant financial information, present it in a form that will be acceptable by a court of law for adequate adjudication of law on perpetrator of economic frauds and crimes. It covers three main areas for clear understanding and easy comprehension. Gathering and preparation of accounting information, involvement of court of competent jurisprudence for proper adjudication and convicting of criminals that commit the economic crime.

Obviously, no financial crime can be disentangle without making recourse to the financial records of the organization, and as such, prior knowledge of statement of accounts and preparation become necessary. Necessary statement of account that will reveal necessary financial activities of an organization will includes: statement of comprehensive income, statement of cash-flow, statement of financial position as at the end of a period and other relevant financial statements. Other areas that will be necessary for clear understanding of fraud includes ethics and code of conduct of the organization involved, accounting standards and financial regulations that surface from time to time. Various opinions emerges but the value ability of the concepts of ethics in decision making process becomes imperative. There are no hard and fast rules in application of professional ethics in the discharge of accounting functions but the concept become very important to the extent that it could influence professional judgment in decision making in an organization or to the requesting entity/ client. Forensic accounting is capable of disentangle varieties of financial crimes and frauds which ranges from issues like:

Insurance- claim frauds, insolvency, skimming's, forgery, keeping of incomplete records, falsification of financial figures and falsification of figures of importance to economic development of any entity. To reduce frauds to its 
barest minimum will take a nation a lot of proactive measures which though readily available but some mechanistic forces always halts efforts channel towards the reduction of this menace. It is therefore the prerogative objectives of this study to exposits the strategies that can unfold the secrecy of the halt in the wheel of vehicle of progress of this nation.

\section{Theoretical Framework}

Forensic Accounting is the usage of accounting skills to investigate frauds and cases of embezzlements reported or anticipated for proper presentation and adjudication by a competent court of law for legal proceedings. It involves proper analysis of financial information that describes engagements that often result from actual or anticipated disputes or litigation. It utilizes auditing and investigation skills of accountant to conduct an examination on company's financial statements for evidence gathering and reporting and to provide accounting data after critical analysis in order to provide suitable information for court of law to prosecute offenders on financial crimes. It is the science of investigation and evidences gathering to establish facts and figures reported officially on verifiable financial fraud for the court of law to work with. It is all about providing relevant and suitable evidences to support a claim that can be utilized by a court of law. It is the investigation of fraud or manipulation of figures that resulted in the conduct and performance of extremely detailed analysis of financial information. There must be a prepared documents to be presented for litigation purpose in the court of law, hence the coverage of the three main areas for clear understanding and easy comprehension become essential. Gathering and preparation of accounting information, involvement of court of competent jurisprudence for proper adjudication and convicting of criminals that commit the economic crime as depicted below is necessary in financial crime curbing.

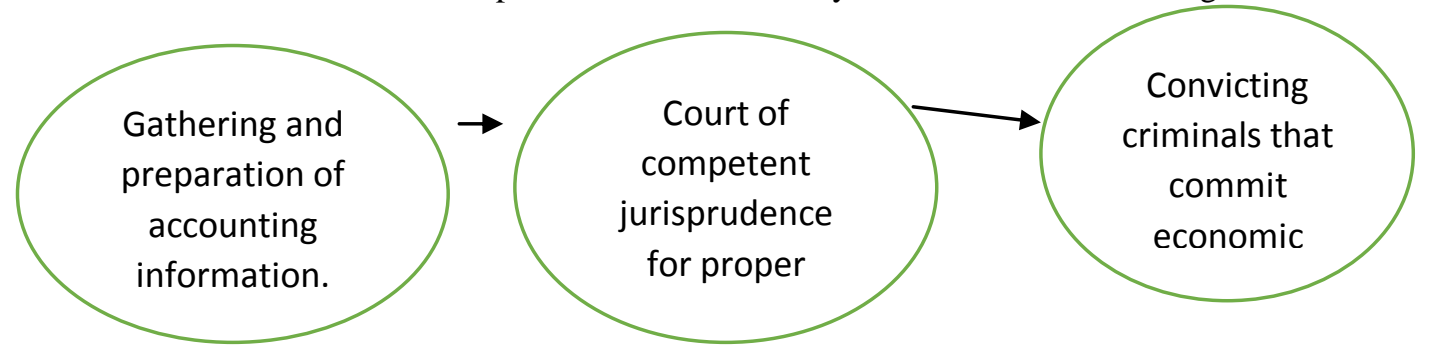

Author's design, 2020

\subsection{FORENSIC EVIDENCE}

This is a term that represents verified facts about a crime reported or anticipated for presentation in court of law hence the forensic accounting is used in supporting the true judgment in the court of law. It precipitated on accounting information which is the science of recording, analyzing and reporting financial transaction of an organization for the purpose of information provision that will guide prospective users in making prudent decisions and in relaying of events and justifications for an action.

\subsection{Financial Crimes and Frauds}

This is a crime of stealing and every other actions of deception which could lead to deriving underserved financial benefits and unlawful gains. The most common ones is cash larceny which is the theft of money that has been recorded in the employers' book, it usually occurred at the collection point, deposit in transits and cash register. It involves cash skimming which also involves theft of money that has not been recorded in the book of the employers. The difference between larceny and skimming is purely on timing. Skimming in a form of a white collar crime of daily receipt from third party and reporting a lower total. It can also be referred to legally as defalcation. Factors like poor remunerations, poor internal control, inadequate training of financial personnel, bad management, lack of detailed operational manual staff infidelity, poor conduct of Accountants, social factors and societal factors has been identified as major causes of financial crimes and frauds in Nigeria.

\subsection{Frauds and Crimes Minimization Strategies}


Strategies like privacy information disclosure through whistle blowers, divorce proceedings, public education and orientation against frauds, legislationagainst all types of frauds- internet frauds inclusive, proper internal control, fighting frauds with technology through detective software and most importantly discouraging the youths from cash bribe called gifts from the politicians that always see youth as a voting instrument even against their wish and other strategies had been decried in the economy to the detriment of the youth and up-coming citizenry. Other strategiesincludes activities like fraud investigation, damages gratifications,company valuation and assessment of tax bills were often discountenanced in the process of curbing financial crimes in developing economy as opposed to what obtains in developed economy all over the world.

\subsection{How to prevent larceny and skimming:}

The preventive measures will be to safeguard your personal property. Safe carriage of your valuables, carry money you actively need, carry only small cash - cashless policy is okay and be careful with anything that have sentimental value in Nigeria

These crimes are curb able by forensic accounting and as such frauds and crimes that are on course or reportable includes financial theft (customer, employee or outsider), security fraud, bankruptcy, defaulting of debt, economic damage, tax evasion or fraud, corporate valuation disputes, professional negligence, claim, money laundering and so on. The money laundry is the concealment of the origin of illegally obtained money by means of transfer involving illegitimate business. It is very pandemic and often perpetrated by big politicians who instead of enveloping there economy prefer to steal and invest such money across the border.

\subsection{Competency Required by a Forensic Accountants}

To be able to function effectively, a potential forensic auditor should possess professional skills in accounting professional ethics and ability to financial statements with proper analytical skills.

\subsection{Principles Governing Audit of Financial Statements}

Auditing practice Board's statement of auditing states that - the objective of an audit of F/S is to enable auditors to give an opinion on those $\mathrm{F} / \mathrm{S}$ taken as a whole, and provides reasonable assurance that it gives a true and fair view and that it has been prepared in accordance with relevant accounting and other requirements. The standard state further that the matters that must be considered in undertaken audit of F/S includes;

(i) Procedure design as a procedures designed to obtain sufficient and appropriate evidence in accordance with auditing students so as to establish reasonable confidence that the statement are free from material misstatements.

(ii) Evaluation of overall presentation: This will allow for ascertainment of whether relevant legislation and statement have been followed.

iii) Issuance of a report:This is the expression of auditors' opinion on the F/S. Statement of affairs of the entity as in SCL, SFP, and compliance with CAMA CAP C20,LFN 2004.

\section{Methodology}

Strategically collected data towards minimizing fraudulent activities and crimes in developing economy were gathered through the administration of questionnaire, analyzed and interpreted with research instrument in consonance with the study objective.

Table 1: The demographic distribution of respondents were: DISTRIBUTED Q ESTIONNAIRE

\begin{tabular}{|l|l|l|l|l|}
\hline & Frequency & $\%$ & Valid Percent & $\begin{array}{l}\text { Cumulative } \\
\text { Percent }\end{array}$ \\
\hline
\end{tabular}




\begin{tabular}{|ll|l|l|l|l|}
\hline Valid & RETURNED & 240 & 82.8 & 94.1 & 94.1 \\
& UNRETURNED & 15 & 5.2 & 5.9 & 100.0 \\
& Total & 255 & 87.9 & 100.0 & \\
Missing & System & 35 & 12.1 & & \\
Total & 290 & 100.0 & & \\
\hline
\end{tabular}

\section{Source: Researcher's Computations from SPSS 22 Output, 2020.}

To validate the potency strategies to minimize fraud and crime in developing economy, two hundred and ninety questionnaires were distributed, two hundred and fifty five (255) were retrieved $94.1 \%$ were returned while $5.9 \%$ of them were unreturned. This is an indication that a very high parentage of the administered questionnaire were completed and returned and respondents are much interested to see to minimization of the menace .The age bracket of the respondents showed more of youth as $63.8 \%$ of the respondents were between $28-47$ years, $4.2 \%$ of them were between $48-57$ years while $9.6 \%$ of them were 58 years and above. From this empirical evaluation, most of the surveyed respondents in this study were between $28-47$ years of age.

\section{Data Analysis and Results}

Table 2: Observed Data on the Role of Forensic Accountant towards eliminating Fraud

\begin{tabular}{|l|l|l|l|l|l|l|}
\hline Items & A & SA & U & D & SD & Total \\
\hline 1 & 93 & 88 & 11 & 21 & 27 & 240 \\
\hline 2 & 94 & 96 & 6 & 22 & 22 & 240 \\
\hline 3 & 98 & 83 & 3 & 27 & 29 & 240 \\
\hline 4 & 98 & 86 & 4 & 22 & 20 & 240 \\
\hline 5 & 84 & 89 & 10 & 37 & 30 & 240 \\
\hline TOTAL & 467 & 442 & 34 & 129 & 128 & 1200 \\
\hline
\end{tabular}

Source: Field Survey, 2020.

The Z-statistic corresponding to the above distribution is estimated using level of significancetest of $5 \%$ or 0.05 . to obtain $\mathrm{n}=1200, \mathrm{Po}=0.05, \mathrm{Z}=[909-1200(0.05)] /\left[(1200 \mathrm{x} 0.05(1-0.05)]^{0.5}\right.$

$\mathrm{Z}=849 /=7.3587$ and $\mathrm{Z} \approx 115.3736$

Table 3: Also on capability of forensic accounting to reducethe occurrence of fraud and crimecases

\begin{tabular}{|l|l|l|l|l|l|l|}
\hline Items & A & SA & U & D & SD & Total \\
\hline 1 & 89 & 86 & 8 & 24 & 33 & 240 \\
\hline 2 & 90 & 92 & 4 & 26 & 28 & 240 \\
\hline 3 & 95 & 80 & 3 & 30 & 32 & 240 \\
\hline 4 & 94 & 82 & 4 & 31 & 29 & 240 \\
\hline 5 & 89 & 94 & 10 & 22 & 25 & 240 \\
\hline TOTAL & 457 & 434 & 29 & 133 & 147 & 1200 \\
\hline
\end{tabular}

Source: Field Survey, 2020. 
DOI: $\underline{10.51386 / 25815946 / i j s m s-v 4 i 4 p 120}$

Volume: 4 Issue: 4

July to August 2021

https://www.ijjsmsjournal.org

The Z-statistic corresponding to the above distribution is estimated with level of significance of test of $5 \%$ or 0.05 were: $\mathrm{n}=1200, \mathrm{Po}=0.05, \mathrm{Z}=[891-1200(0.05)] /\left[(1200 \times 0.05(1-0.05)]^{0.5}\right.$

$\mathrm{Z}=831 / 7.3587$ and $\mathrm{Z} \approx 112.9276$

\section{Test of Hypotheses}

The following hypotheses were tested using the Z-statistic at 5\% level of significance:

Ho :Forensic Accountant is not capable of eliminating and significantly reduce the occurrence of fraud cases in the developing economy. Thus, if the estimated Z-statistic is less than or equal to the critical table value off the Zstatistic at 5\% level of significance, the null hypothesis is accepted otherwise, the alternative hypothesis is accepted.

$\mathrm{Z}=\frac{\mathrm{x}-\mathrm{npo}}{\sqrt{\mathrm{npo}(1-\mathrm{po})}}$
$\mathrm{n}=1200, \mathrm{Po}=0.05, \mathrm{Z}=[909-1200(0.05)] /\left[(1200 \mathrm{x} 0.05(1-0.05)]^{0.5,} \mathrm{Z}=849 /=7.3587\right.$
$\mathrm{Z} \approx 115.3736$

The estimated Z-statistic was estimated as shown above at 115.3736.The critical table value of the Z-statistic at 5\% level of significance( $95 \%$ confidence level) was obtained as 1.645. Since the estimated test statistic (Z-statistic) value exceeds the critical table value at $95 \%$ confidence level, the null hypothesis is rejected in favour of the alternative hypothesis. The study therefore concludes that Forensic Accountants is capable of eliminating all types of financial frauds in anyeconomy. It was empirical estimated and found that forensic accounting can be used to locate diverted funds or assets, help to identify misappropriated assets and identify reversible insider transactions, useful as effective fraud detection tool, as a tool to detect suspicious or fraudulent transactions and that risk assessment processes under forensic accounting specifically cover risk of fraud of any form. The strategies often employed to curb frauds and all source of crime revealed thatsteps of reducing the occurrence of fraud cases using forensic accounting include: implementing external controls, plans and programs to secure the organization's assets, rotating employees to various jobs within the organization, hiring external experts to put fraud policies in place, proper education and orientation against fraud of any forms, legislation against all forms of crime, using software to fight corruption and ensuring conducive work environment for employees within the organization.

\section{Conclusion and Recommendations}

With respect to the empirical analysis carried out in this study, it was estimated that forensic accounting is capable of locating diverted funds and assets, identified misappropriated assets. Be a useful detection tool, detect suspicious or fraudulent transactions andrisk assessment processes are adequately covered. The study therefore concludes thatforensic accounting is cap[able of eliminating frauds and crimes in the developing economy if given enabling supports through legislation and unhindered supervision by court of law. Forensic Accounting principles were found to be significantly relevant and capable of reducing the occurrence of fraud of any form with the supports of government and removal of unnecessary benevolence of political powers.

Based on the above, the study recommends the adoption of forensic accounting principles, ensuring effective appropriation of financial resources in an organization and external auditors' employment to audit the finances of organization frequently so as to enable them carry out their functions without fear or favour.

\section{REFRENCES}

[1] Aljalili, M.A(2016). Judicial Accountants and their Applicability in Iraq. Tanmiat Al-Rafidain. 34(17). 9-21

[2] Bhasin, M.L.(2017. Survey of appropriate skills required by forensic accountants. Empirical evidence from a developing economy. International Journal of Accounting and Economic Studies 1(2) 51-73.

[3] Degboro, D. \& J. Olofinjanna, (2017). Forensic Accounting and litigation supports engagement. Nigeria Accountants 40(2) 46-52. 
[4] Gray,D.(2018).Forensic accounting and auditing, American Journal of business education,1(2), 115.

[5] Joshi, M.S. (2017). . Definitions of forensic accounting. www.forensic accounting.com.

[6] Howard, S.A.,M. Sheetz(2016). Forensic accounting and fraud investigation for non-experts. New Jersey, john williey\&Sons,inc.

[7] Mounce, P.H \& I.J. Frazier (2016). The effect of forensic accounting education on accountant's employment potential. Journal of forensic accounting. 3(1)91-102.

[8] Okafor,B. (2013). Strategic Approach to reduction of employee's theft, fraud and embezzlement. Nigeria Accountants, $37(4), 3$-5.

[9] Oyejide, A, (2018). Corruption and development. A Nigerian perspective. Nigerian Accountantans 41(4), 28-42.

[10] Ozkul, F.U, \& A. Pamukc, (2014). Fraud detection and forensic Accounting. Istanbul, Turkey.

[11] Karwai, S.A (2014). Bank fraud: CanShariaprevent it? Journal of Business Administration 2(1)62-67.

[12] Pickett, K.\&J.Pickett, (2016). Financial crime investigation and control N.Y. Wiley \& Sons.

[13] Porter, S.F, \& D.L. Crumbley (2016). Teaching interview techniques to forensic accountants is critical. Journal of forensic and investigative Accounting.4(1):122-126. 